\title{
Status of Coral Reef Communities on Two Carbonate Platforms (Tun Sakaran Marine Park, East Sabah, Malaysia)
}

\author{
A. Montagne, ${ }^{1}$ O. Naim, ${ }^{1,2}$ C. Tourrand, ${ }^{2,3}$ B. Pierson, ${ }^{4}$ and D. Menier ${ }^{1,5}$ \\ ${ }^{1}$ Géosciences Marines et Géomorphologie du Littoral, Laboratoire Domaines Océaniques, UMR 6538 CNRS, Université de Bretagne \\ Sud (UBS), 56000 Vannes, France \\ ${ }^{2}$ Laboratoire ECOMAR, Université de la Réunion (UR), 97460 Sainte-Clotilde, France \\ ${ }^{3}$ Département de Physique, Université de la Réunion (UR), 97460 Sainte-Clotilde, France \\ ${ }^{4}$ South-East Asia Carbonate Research Laboratory (SEACARL), Universiti Teknologi, Petronas, 31150 Tronoh, Perak, Malaysia \\ ${ }^{5}$ Department of Geosciences, Universiti Teknologi, Petronas, 31150 Tronoh, Perak, Malaysia
}

Correspondence should be addressed to O. Naim; odile.naim@orange.fr

Received 12 March 2013; Revised 29 May 2013; Accepted 26 August 2013

Academic Editor: Luiz E. Aragao

Copyright @ 2013 A. Montagne et al. This is an open access article distributed under the Creative Commons Attribution License, which permits unrestricted use, distribution, and reproduction in any medium, provided the original work is properly cited.

\begin{abstract}
This study concerns three sites, located on carbonate platforms, east Sabah: Gaya West, Gaya East, and Mantabuan. At each site, the dominant coral shapes and their health were recorded (lagoons and outer slopes). Densities of echinoderms, Tridacna, and nudibranchs were recorded while fish density was estimated. Generally, the coral vitality is low ( $\leq 50 \%$ living corals). Massive corals dominate all sites, except the Gaya West-outer slope where coral coverage and diversity are the highest. On the Mantabuan-mesh reef, a diverse Acropora assemblage dominates the landscape. On the reef flat of Gaya East, monospecific circa 10 meter coral patches occur. Primary producers are scarce on all sites. Sea urchins, dominated by Diadema, are abundant on the Gaya East-reef flat and the Gaya West-mesh reef. Sea stars and holothurids are the most prevalent in Gaya West-outer slope, although they remain scarce. Crinoids are only abundant in Mantabuan. Stegastes damselfish highly characterizes the sites of Gaya East (reef flat and inner slope) and the Mantabuan-mesh reef. On the Mantabuan-outer slope, parrotfish and other fishes are plentiful. No sign of eutrophication has been detected and natural hypersedimentation and/or eventual ancient bleaching events appear to be the direct principal causes of coral death or coral degradation.
\end{abstract}

\section{Introduction}

An exceptionally high biodiversity prompted the creation of the Tun Sakaran Marine Park (TSMP) in the western part of the Celebes Sea, east of Semporna, Sabah, Malaysia, as the site supports a greater diversity of marine species than recorded elsewhere in Malaysia. The site is therefore of regional, national, and local importance.

Marine and coastal habitats include (1) mangroves, (2) seagrass beds, (3) lagoons, (4) fringing, patch and bank reefs and (5) open water. Studies show that the diversity of marine species in the proposed park is very high. There are over 600 species of fish and at least 250 species of corals $[1,2]$. Harborne et al. [3], summarizing fragmented studies of coral species' richness around Malaysia, reported a total of 323 species. Around the reefs, 265 species of molluscs occur [4], and there may be as many as 140 species of sponges, 70 species of soft corals, and at least 50 species of gorgonians $[5,6]$. In addition, a high diversity of echinoderms exists, with a total of 109 species recorded $[5,7,8]$. Several of the sponges and soft corals found in the Gaya lagoon are new undescribed species. One sponge is very unusual and possibly endemic to the Semporna reefs [9]. Also, Allen [1] found two new species of damselfish.

The preliminary results of the Semporna Marine Ecological Expedition [10] (http://awsassets.panda.org/downloads/ smee_factsheet_dec_2010.pdf) indicate that Semporna may have one of the world's highest marine biodiversity. For example, the expedition's fish counts demonstrated that Semporna is one of the richest areas within the Coral Triangle (844 species of fish encountered). Also, the expedition yielded 
a record number of 43 species of mushroom corals (the previous highest recorded richness in this family was 40 species in Indonesia and Papua New Guinea). Furthermore, some new species were discovered (two species of shrimp and possibly a number of gall crabs).

In Semporna, the island of Bodgaya was first gazetted in 1933 as a forest reserve, and the island of Boheydulang was proposed as a bird sanctuary. Then in 1977, proposals were made to establish a state park. Later, in 1998, a collaboration (known as the Semporna Islands Project) was set up between the Marine Conservation Society (MCS), Sabah Parks, WWF Malaysia, and Nature Link. In 2004, the Tun Sakaran Marine Park (TSMP), the seventh gazetted area under Sabah Parks, was established.

Over 2,000 residents, that is, Suluk, Bajau, and Bajau Laut, live in the TSMP. This unique mix of people adds a further dimension to the area through their cultures, lifestyles, legends, and skills. Most of the islands have settlements made up of semipermanent houses, shacks, and permanent structures. The main activities consist of fishing, gardening, and seaweed cultivation. The natural products harvested are fish, shellfish, medicinal plants, fruits, and timber. Tourism is currently almost nonexistent, although 21 prestigious scuba diving sites are reported [11].

Herein, reticulated reefs, commonly known as mesh reefs, are particularly studied. Complex cellular patterns of coral reef walls or "reticulated/mesh reefs" often occupy the small fringing reefs and the internal lagoons of several modern platforms in the Tun Sakaran Marine Park. They are networks, with intervening depressions, of linear or polygonal reef framework. The cellular patterns are of different sizes and scales: cells $20 \mathrm{~m}$ in diameter, larger cells $200 \mathrm{~m}$ in diameter, and the largest (on Selakan Bank) about $1 \mathrm{~km}$ in diameter $[12,13]$. These reef patterns may occur (1) on fringing reefs, notably in the Arabian Gulf, in the Red sea $[14,15]$, and in Madagascar [16], (2) on barrier reefs in New Georgia [17], in Belize [18], on the Great Barrier Reef [1921], and in Mayotte [16], and (3) on atolls in Hawaii (Maro reef, [22]), in Fiji, in French Polynesia [23, 24], and in Kiribati (Caroline/Millennium, [25]). According to Montaggioni [23] and Purkis and Riegl [15], the reticulated shape of the mesh reef could mimic a preexisting karst topography, inherited from an episode of lower sea level.

The aim of the study is to analyze the health and stage of development (old corals or recovery after mortality) of coral communities in two islands (reticulated reefs in lagoons and outer slopes). The density of associated organisms, echinoderms, gastropods, bivalves, and fishes, are coanalyzed.

\section{Material and Methods}

2.1. General Environmental Setting. Sabah is a tropical country characterized by uniform temperatures, high humidity, and copious rainfalls. Situated between roughly $4^{\circ} \mathrm{N}$ and $7^{\circ} \mathrm{N}$, under the monsoon and typhoon belt, Sabah is often referred to as "the Land below the wind." Generally two seasons are distinguished: the rainy and the dry seasons although it is hot and humid (85-95\%) almost all year round, except at highaltitude. In most parts of Sabah, the wet season starts in November with the onset of the Northeast Monsoon (winter monsoon) and ends towards March. During the months of April to November, the drier season occurs (southwest monsoon or summer monsoon), and southwesterly winds over the northwest coast of Sabah may strengthen, reaching $40 \mathrm{~km} \cdot \mathrm{h}^{-1}$ or more. In Semporna, temperatures rarely rise above $32^{\circ} \mathrm{C}$ during the day and rarely drop below $23^{\circ} \mathrm{C}$ at night. Seawater is almost at a constant temperature (26$\left.29^{\circ} \mathrm{C}\right)$.

Tun Sakaran Marine Park (TSMP), also known as Semporna Islands Park, lies off the east coast of Sabah, Malaysia, at the entrance to Darvel Bay (latitude $4^{\circ} 33^{\prime} \mathrm{N}$ to $4^{\circ} 42^{\prime} \mathrm{N}$ and longitude $118^{\circ} 37^{\prime} \mathrm{E}$ to $118^{\circ} 51^{\prime} \mathrm{E}$ ) (Figure 1). It is the largest marine Park in Malaysia and one of the prime coral reef sites of the country. It includes eight islands and associated reefs (Bodgaya, Boheydulang, Sebangkat, and Selakan, the sand cays of Maiga, Sibuan, and Mantabuan, the patch reefs of Church and Kapikan) and covers an area of approximately $340 \mathrm{~km}^{2}$ of sea and coral reefs and $10 \mathrm{~km}^{2}$ of land. The large, central high islands are formed of volcanic rock and are unique in Sabah. The outlying islands are low limestone and carbonate sand cays. Their windward margin, where coral reefs develop, faces the dominant northeast trade winds.

In the studied area, the maximum high tide recorded in the tide tables for Semporna (Darvel Bay) is $2.1 \mathrm{~m}$ and the minimum tide, $0.1 \mathrm{~m}$ (http://www.mareespeche.com/as/ malaysia/semporna-darvel-bay).

2.2. Studied Sites. Three monitoring sites were selected on Gaya and Mantabuan Banks (Figure 1). Gaya Bank is a true atoll, about $8 \mathrm{~km}$ in diameter, with a perimeter of $30 \mathrm{~km}$. An extinct volcano, at the core of the bank, forms two high relief islands, Pulau Bodgaya and Pulau Boheydulang. A reef complex and associated facies mainly developed on the seaward side of the volcanic islands. The deep lagoon may represent the crater of the extinct volcano. Intricate, polygonal patterns of reef walls, or mesh reefs of different sizes occupy the lagoon. Mantabuan is a smaller bank, $8 \mathrm{~km}$ in perimeter, located in the NE of Gaya bank.

The studied sites (Figure 2) display different types of reef habitats occurring on the carbonate platforms: (1) site GE includes a fringing reef exposed to currents (reef flat and internal slope), (2) site GW includes a part of a large mesh reef, a reef rim, and an outer slope, (3) site $M$, an outer, clear-water site, includes a part of the mesh reef, a reef rim, and an outer slope. As the coral coverage decreases sharply below $15 \mathrm{~m}$ in depth, slopes were explored up to this depth (Figure 3).

In the results, we will often separate one site into two subsites: the lagoon or reef flat and the slope. Methods are detailed in Table 1.

Survey 1: ReefZonation and Major Benthic Categories. To provide information on reef zonation, the habitat was observed and the major components were analyzed. The surveyor measured depth, current speed and recorded the abundance of main components of the sessile benthic community. 
TABLE 1: The three surveys.

\begin{tabular}{|c|c|c|c|c|}
\hline & Aim of the study & Stations & Method & Period \\
\hline Survey 1 & $\begin{array}{l}\text { Sessile fauna: estimation of coverage and species } \\
\text { composition of major benthic categories }\end{array}$ & $\begin{array}{l}\text { At each site, LITs are parallel } \\
\text { to the reef front }\end{array}$ & $\begin{array}{l}\text { Line-Intercept-Transect }= \\
10 \mathrm{~m} \text { LIT }\end{array}$ & 2011, May \\
\hline Survey 2 & $\begin{array}{l}\text { Sedentary fauna: estimation of densities of } \\
\text { echinoderms, Tridacna, and nudibranchs }\end{array}$ & $\begin{array}{l}1 \text { belt-transect, } 0.5 \mathrm{~m} \text { apart the } \\
50 \mathrm{~m} \mathrm{LIT}\end{array}$ & $\begin{array}{l}\text { Belt-transect } \\
(50 \mathrm{~m} \text { by } 1 \mathrm{~m})\end{array}$ & 2011, May \\
\hline Survey 3 & $\begin{array}{l}\text { Fishes: abundance index for: } \\
\text { (1) Damselfish Stegastes(2) Parrotfish } \\
\text { (3) Other fishes }\end{array}$ & $\begin{array}{l}1 \text { belt-transect, } 0.5 \mathrm{~m} \text { apart the } \\
50 \mathrm{~m} \mathrm{LIT}\end{array}$ & $\begin{array}{l}\text { Belt-transect } \\
(50 \mathrm{~m} \text { by } 1 \mathrm{~m})\end{array}$ & 2011, May \\
\hline
\end{tabular}

LIT: Line-Intercept-Transect.

$118^{\circ} 10^{\prime} \mathrm{E}$

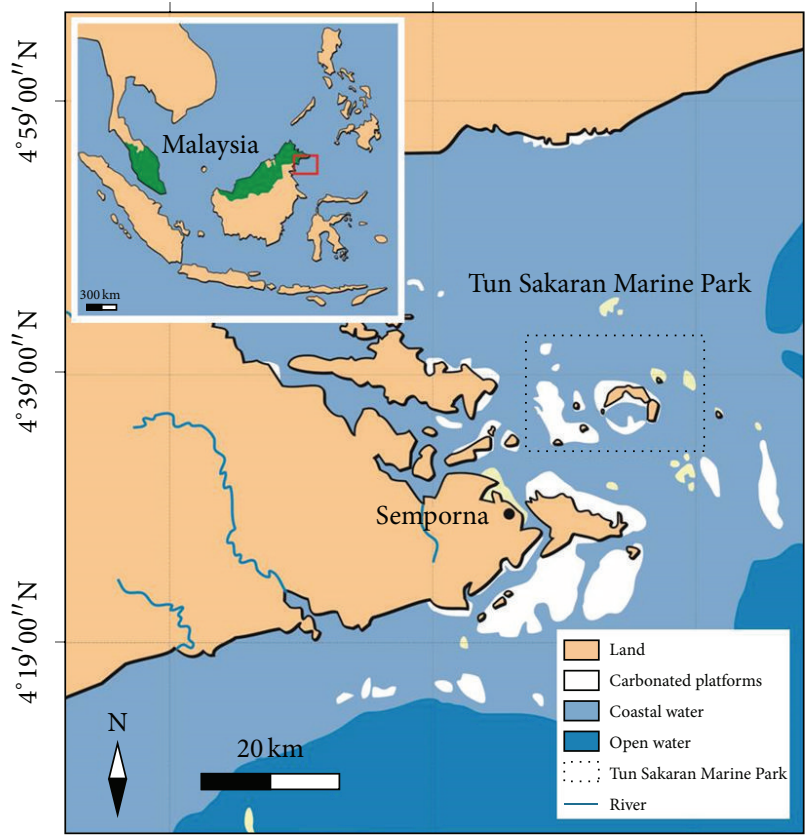

(a)

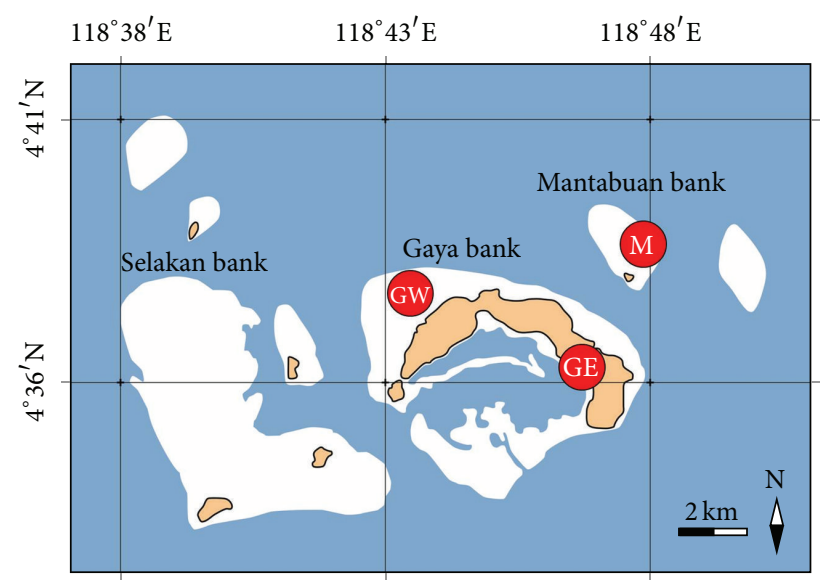

(b)

FIgure 1: (a) Location of the Tun Sakaran National Park in Malaysia; (b) focus on the three studied sites: Gaya West (GW), Gaya East (GE), and Mantabuan (M).

Using the Line-Intercept-Transect (LIT) method [26, 27], an estimation of the coverage (in \%) of major benthic sessile categories (such as primary producers, living and dead corals, soft corals, sponges, rock, sand, and rubble) was made at a 5 -centimeter resolution. LITs, $50 \mathrm{~m}$ in length, parallel to the front of the reef, were run at different intervals (Figure 2).

Primary producers are cyanophytes and benthic algae; bare dead corals are the dead substrates that are not covered by any living organism visible to the naked eye.

The different forms of corals have been noted as follows: ACB: branching Acropora; ACBB: bottlebrush Acropora; ACCOR: corymbose Acropora; ACST: stout Acropora (A. palifera); ACTAB: tabular Acropora; CB: branching nonAcropora (such as branching Porites, Pocillopora, Stylophora, and Seriatopora); CENC: encrusting Non-Acropora; CF: foliaceous corals (such as some Montipora, some Pavona, and Turbinaria); CM: massiveNon-Acropora (such as massive Porites, Faviidae); CMR: mushroom corals (Fungia, Cycloseris, Herpolitha, etc.); CSM: submassive corals (some Montipora, Psammocora, etc.); CST: stout branching nonAcropora.

In the lagoon, LITs had to be located on the upper part of the mesh rims and not at random, because of the great height of the coral rims (Figure 3).

Unlike in a classical reef check, we analyzed all the layers of the communities (Figure 4), for example, the dead substratums, on which young corals are settled, young corals on which perhaps algae are settled, and so forth.

Survey 2: Densities of Echinoids, Holothurids, and Stegastes. Densities of Echinoderms (echinids, asterids, holothurids, crinoids), Tridacna, and nudibranchs were censused in belttransects, $0.5 \mathrm{~m}$ strip on either side of each $50 \mathrm{~m}$ LIT $\left(50 \mathrm{~m}^{2}\right)$. 
TABLE 2: Description of the three radial lines on the three sites, Gaya West, Gaya East, and Mantabuan, from the lagoon to the reef rim and the outer slope.

(a)

Gaya West
The mesh reef in the lagoon
(stations GW1 to GW5)

The mesh reef in the lagoon
(stations GW1 to GW5)

The transition from the lagoon to
the reef rim
the reef rim

The outer slope (stations GW6 and
GW7)

The sandy plain

Gaya East

The back reef (GE1 station)

The reef flat (GE2 to GE5
stations)

The reef rim
The inner slope (GE6 and GE7
stations)

\begin{tabular}{ll}
\hline \multirow{2}{*}{ The sandy plain } & $-17 \mathrm{~m}$. \\
\hline & Depth: $-17 \mathrm{~m}$ \\
Turbidity is not important.
\end{tabular}

(c)

\begin{tabular}{|c|c|c|}
\hline Mantabuan & Depth, turbidity, and currents & Description of the general morphology \\
\hline $\begin{array}{l}\text { The mesh reef into the lagoon } \\
\text { (M1 to M4 stations) }\end{array}$ & $\begin{array}{l}\text { Depth: }-1 \text { to }-5 \mathrm{~m} \\
\text { The water is not turbid. }\end{array}$ & $\begin{array}{l}\text { Into the lagoon, corals form a mesh reef. But the } \\
\text { strips, } 4 \mathrm{~m} \text { high and } 3 \mathrm{~m} \text { wide, are less developed } \\
\text { than in the Gaya West lagoon. The coral community } \\
\text { is diverse, and Acropora is abundant. The upper parts } \\
\text { of the strips are subtidal. }\end{array}$ \\
\hline
\end{tabular}

Description of the general morphology

In the lagoon, corals form a mesh reef made of large coral strips, 4-7 $\mathrm{m}$ high and 4-5 $\mathrm{m}$ wide. These coral rims rise from the seabed like large walls, part of the strips never emerges at low tide. Coral vitality is low.

Depth: $-2 \mathrm{~m}$.

It is possible to walk on this part of the reef at low tide.

Currents are very strong, and,as a consequence, the area has not been analyzed.

From the lagoon toward the reef rim, the depth decreases sharply. In this transition zone, corals occur as circa metric patch reefs with great vitality. These patches are scattered in a large sandy area. Coral colonies are likely massive and submassive and few Acropora are visible.

The reef rim is the highest part of the intertidal portion of the reef, reaching a few centimeters above the upper level of coral growth. Here it is half-necrotic and is less than $10 \mathrm{~m}$ wide. Coralline algae cements the upper surface of the rim.

From 0 to $15 \mathrm{~m}$, turbidity is not The outer slope is very steep and displays luxuriant important, and coral diversity is the hard corals, dominated by large heads of highest observed at Gaya West. non-Acropora corals.

Depth: $-15 \mathrm{~m}$.
Turbidity is very important.

At $-15 \mathrm{~m}$ depth appears a plain characterized by slightly muddy fine sediment.

(b) Depth, turbidity, and currents This part of the reef is made of sand. The currents may be high during tides.

\section{Description of the general morphology}

No hard coral is visible. Some scarce starfish occurs there.

Depth: -4 to $-2 \mathrm{~m}$.

The water is not turbid. Because of the location behind a corridor occurring between the two islands, Pulau Bodgaya and Pulau Boheydulang, the currents may be violent during tides.

The reef flat is characterized by monospecific, circa $10 \mathrm{~m}$ in diameter, stands of branching Acropora, foliaceous Montipora, cfflorida, or Pavona cactus. These large stands alternate with more diversified and smaller patches of branching, submassive, and massive non-Acropora (Pocillopora, Stylophora, Seriatopora, Psammocora, Favia, Favites, etc.).

Depth increases slowly. There is no reef rim visible.

From -2 to $-15 \mathrm{~m}$. First the slope gently goes down from -2 to $-7 \mathrm{~m}$ for 50 meters and then becomes steeper from -7 to The two stations GE6 and GE7 are located in the steep area $(-10$ and $-15 \mathrm{~m})$.

At $-17 \mathrm{~m}$ appears a plain made of fine sediment. surrounded by a sandy plain (Figure 5). The upper 
(c) Continued.

\begin{tabular}{|c|c|c|}
\hline Mantabuan & Depth, turbidity, and currents & Description of the general morphology \\
\hline $\begin{array}{l}\text { The transition from the lagoon to } \\
\text { the reef rim }\end{array}$ & $\begin{array}{l}\text { Depth: }-2 \mathrm{~m} \text {, high speed } \\
\text { currents. }\end{array}$ & $\begin{array}{l}\text { Toward the reef rim, the depth decreases, and an } \\
\text { area made of very fine sand occurs with small coral } \\
\text { patches of great vitality. Corals occurring there are } \\
\text { likely massive and submassive, but Acropora is much } \\
\text { more abundant than in the similar zone of Gaya } \\
\text { West. }\end{array}$ \\
\hline The reef rim & Depth: $0 \mathrm{~m}$. & The reef rim appears as a subtidal area. \\
\hline $\begin{array}{l}\text { The outer slope (M5 to M7 } \\
\text { stations) }\end{array}$ & $\begin{array}{l}\text { Depth: from }-2 \text { to }-15 \mathrm{~m} \text {. } \\
\text { Low turbidity and high current } \\
\text { speed. }\end{array}$ & $\begin{array}{l}\text { First the slope gently goes down from }-2 \text { to }-7 \mathrm{~m} \\
\text { (M5 station) and then becomes steep from }-7 \text { to } \\
-15 \mathrm{~m} \text { (M6 and M7 stations). The diversity in corals } \\
\text { is less important than in Gaya West outer slope. }\end{array}$ \\
\hline The sandy plain & $\begin{array}{l}\text { Depth: }-15 \mathrm{~m} . \\
\text { Low turbidity. }\end{array}$ & At $-15 \mathrm{~m}$ appears a plain made of fine sediment. \\
\hline
\end{tabular}

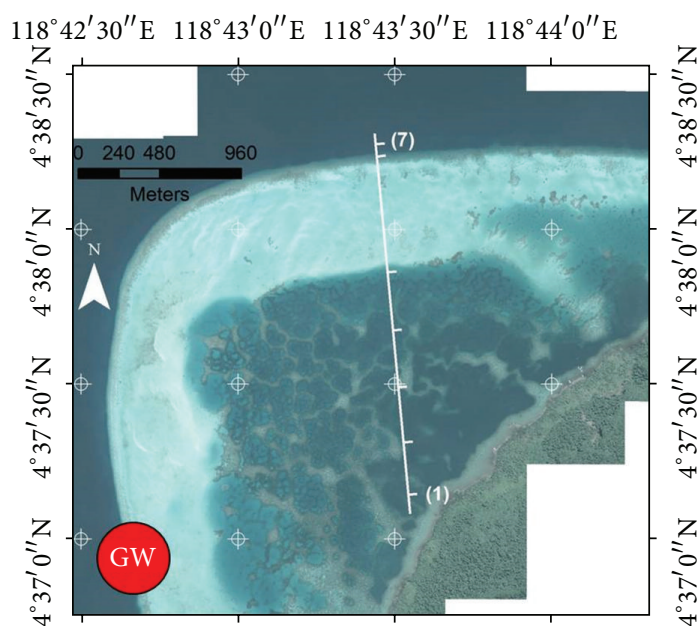

$118^{\circ} 42^{\prime} 30^{\prime \prime} \mathrm{E} \quad 118^{\circ} 43^{\prime} 0^{\prime \prime} \mathrm{E} 118^{\circ} 43^{\prime} 30^{\prime \prime} \mathrm{E} 118^{\circ} 44^{\prime} 0^{\prime \prime} \mathrm{E}$

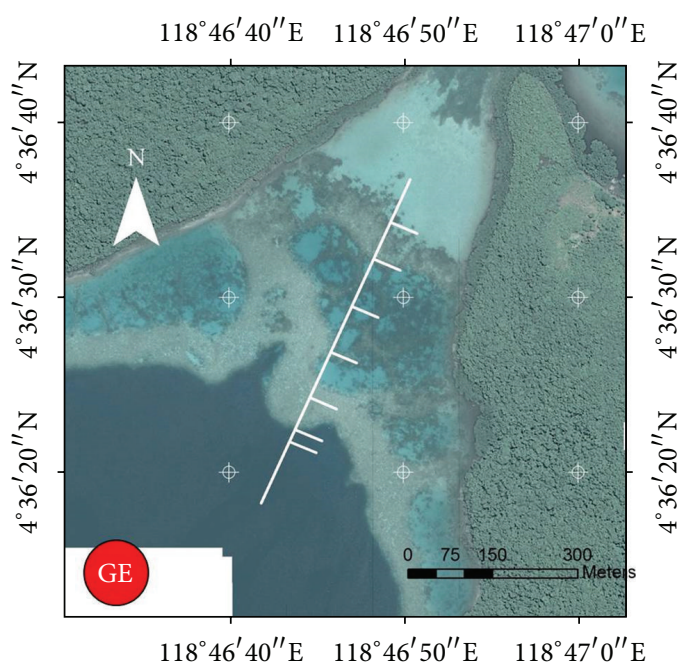

(b)

(a)

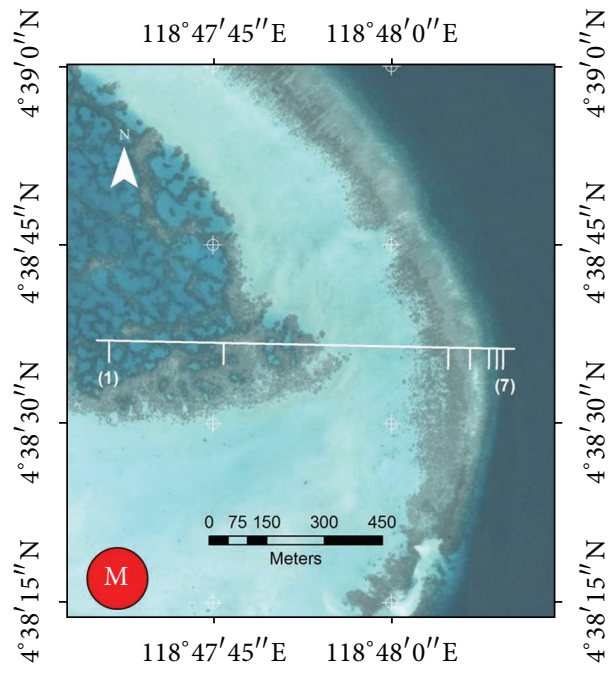

(c)

FIGURE 2: Aerial photography of the three sites with the radial lines and LITs. We can see on aerial photographies of (a) Gaya West (GW), the mesh reef, the rim, and the outer slope, (b) Gaya East (GE), the reef flat and the inner slope, and (c) Mantabuan (M), the mesh reef, the reef rim, and the outer slope. 


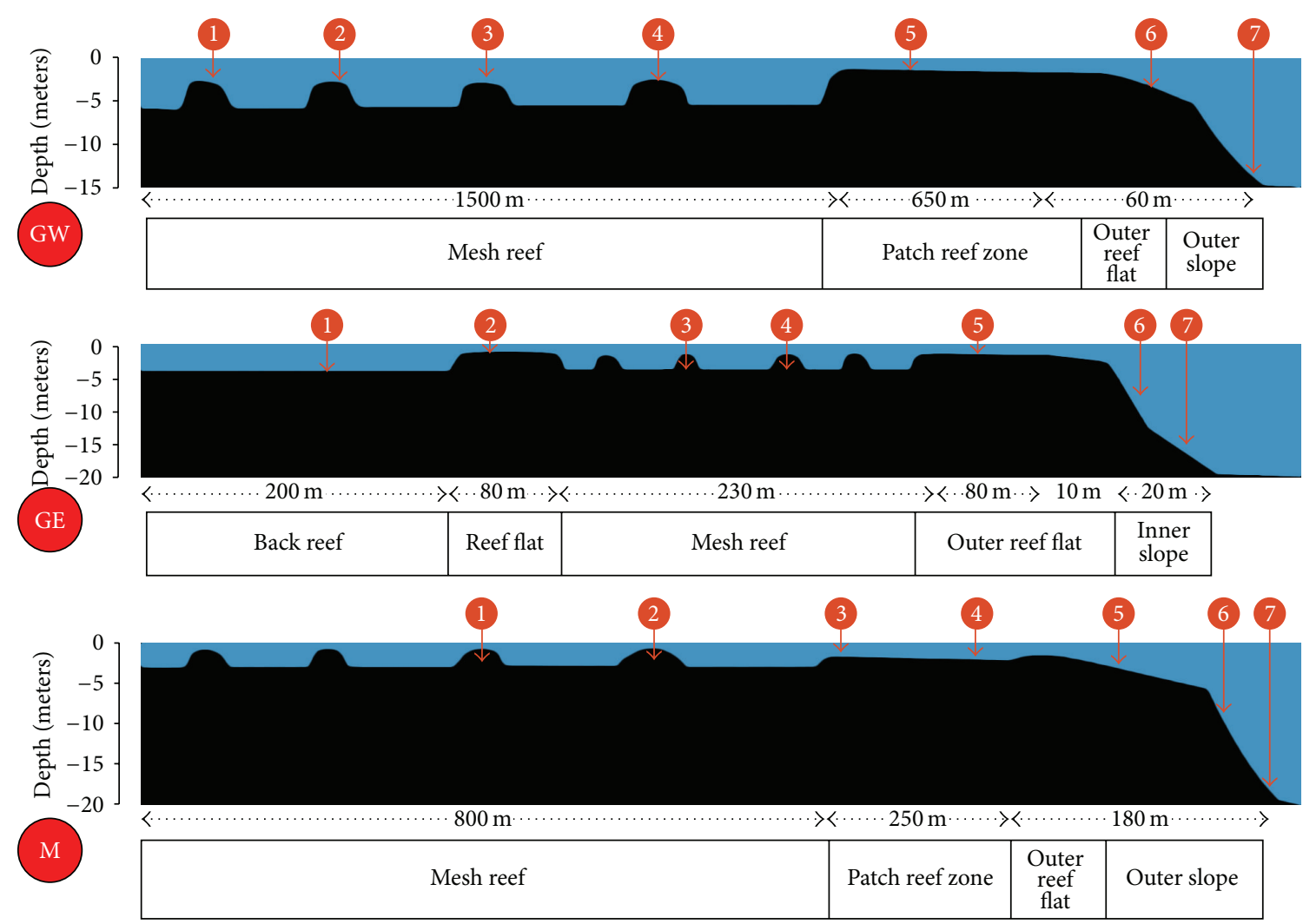

FIGURE 3: The reef profile along the three radial lines, Gaya west (GW), Gaya east (GE), and Mantabuan (M), and the location of the LITs on the different geomorphological zones (not to scale).

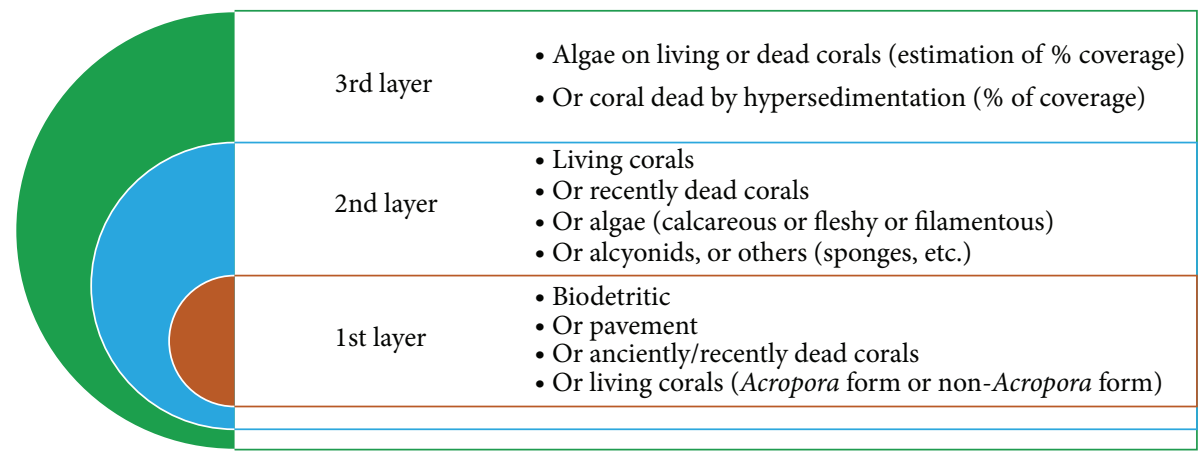

FIGURE 4: The analysis on a LIT: three layers (or more) can occur: all are noted.

All animals, visible from a vertical position as well as those hiding underneath ledges and in crevices, were counted.

Survey 3: Fish Abundance. Fishes are classified into three categories: (1) the territorial damselfish Stegastes, (2) parrotfish, and (3) other fishes. Before echinoderm counting, an abundance index is given to each of the three categories occurring in the $50 \mathrm{~m}$ by $1 \mathrm{~m}$ belt (abundance index $1=2-3$ individuals; $2=5-16$ individuals; $3=17-64$ individuals; $4=$ 65-250 individuals; $5=$ more than 250 individuals).

2.3. Data Analysis. Mean and standard deviation (SD) of sessile fauna data for sites (Gaya West, Gaya East, and Mantabuan) and subsites (reef flat, mesh reef, and inner and outer slope) are calculated by taking one $10 \mathrm{~m}$ LIT as a sample. For sedentary fauna and fish, the sample is the $50 \mathrm{~m}$ by $1 \mathrm{~m}$ belt, thus $50 \mathrm{~m}^{2}$. Due to the multispecies nature of the data and the design of the survey, the most appropriate analyses are multivariate [28]. To assess patterns in benthic data from all stations during all years of survey, we used the principal component analysis (PCA).

\section{Results}

A first description of the radial lines was made to highlight the different subzones (Table 2) and to decide where the LITs have to be settled. 

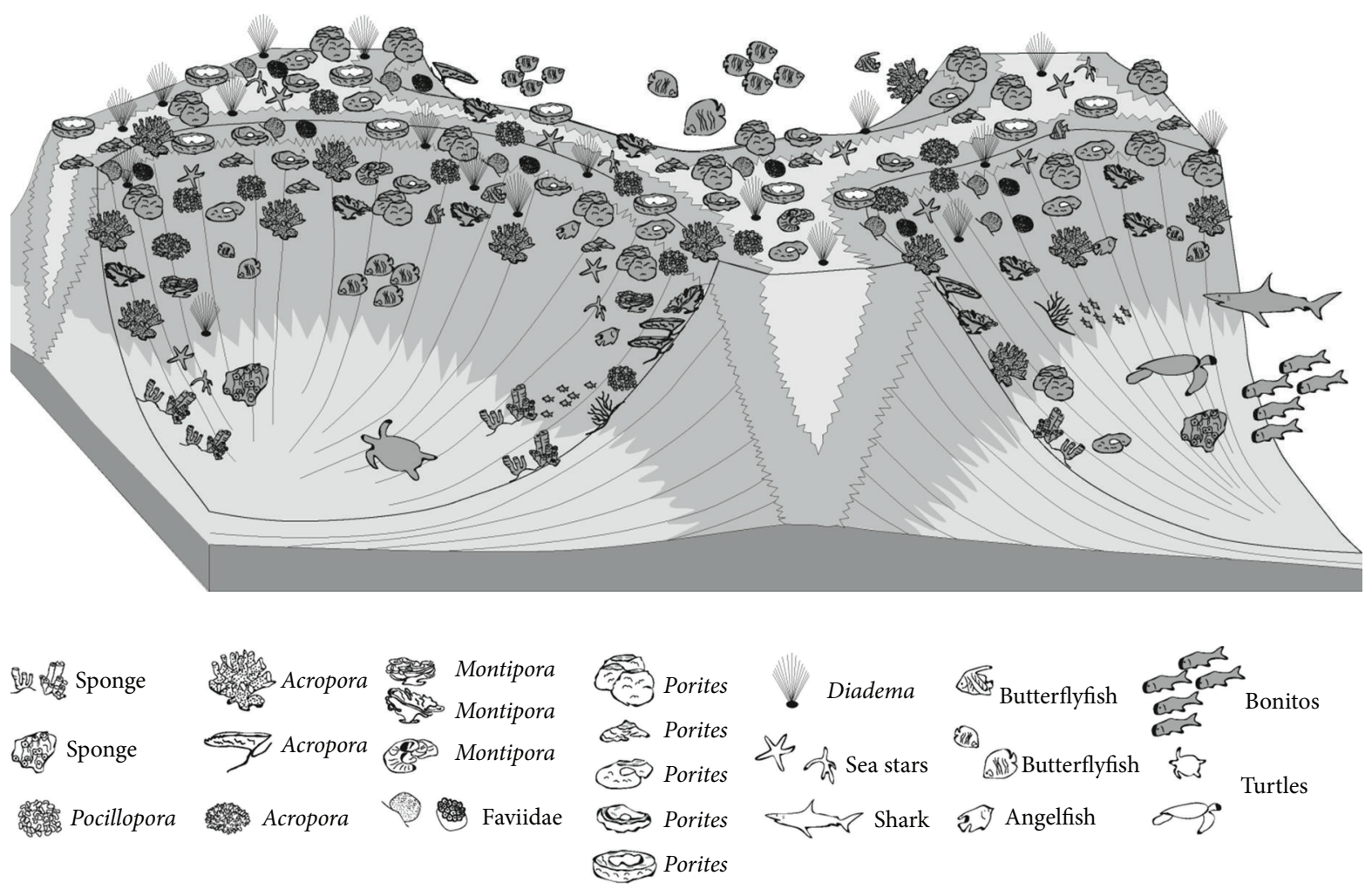

Figure 5: Gaya West lagoon: a part of the mesh reef with associated fauna (no scale).

Different types of substrates on which the macroalgae are settled

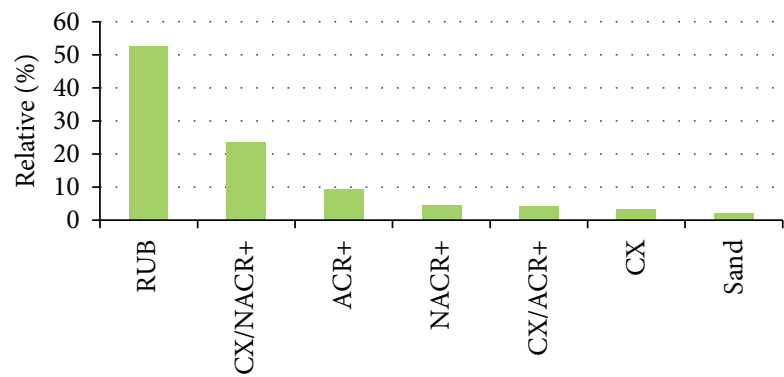

Figure 6: Substrates on which are settled the macroalgae. All stations together. RUB: rubble; ACR+: dead Acropora, NACR+: dead non-Acropora; CX/ACR+: dead Acropora settled on dead substrates; CX/NACR+: dead non-Acropora settled on dead substrates.

3.1. Primary Producers. Among primary producers, the encrusting calcareous algae are not recorded. Although they are ubiquitous, their abundance is below the threshold of the measurement.

The total coverage of filamentous and macroalgae is very low (below 5\%), except on the Gaya East-reef flat (Table 3), where they can be abundant in places (turfs in damselfish territories or macroalgae patches).

Figure 6 shows that the macroalgae are mainly settled on rubble, indicating that few living corals are in competition

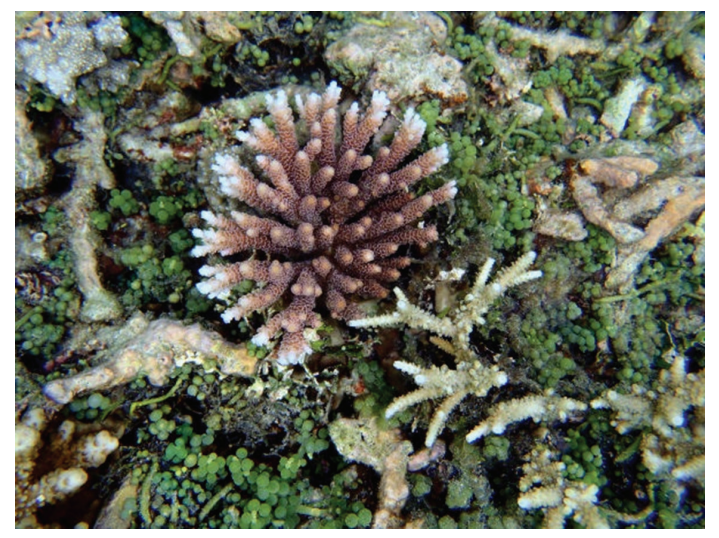

Figure 7: Gaya West, upper part of the mesh reef, Caulerpa racemosa crawling between living and dead Acropora.

with primary producers. On Gaya West-mesh reef, Caulerpa racemosa is abundant, its vesicle-like branchlets along the erect axes crawling between corals (Figure 7). On Gaya East-reef flat, large Ochrophytes, such as Sargassum and Turbinaria, occur on rubble.

3.2. Bioconstructed Substrates. At each site, the studied radial lines spread into the lagoon, the reef rim, and the outer or inner slopes (Figures 2 and 3). Into the lagoon, corals are organized into a reticulated reef in Gaya West and Mantabuan 


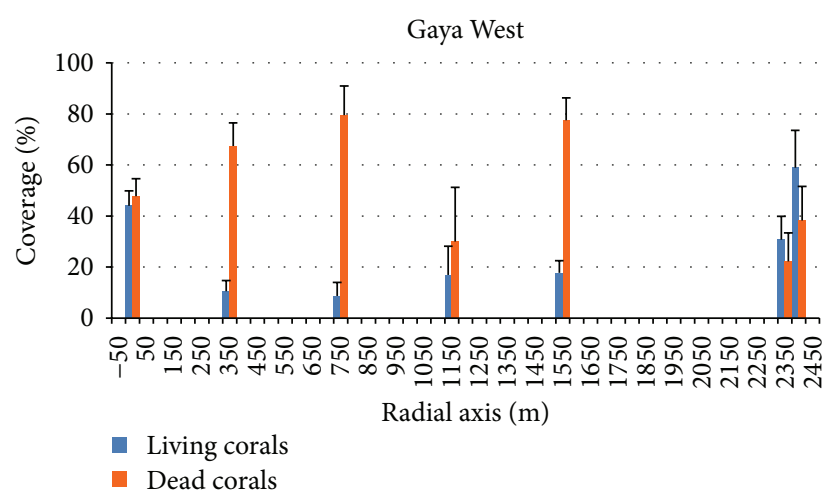

(a)

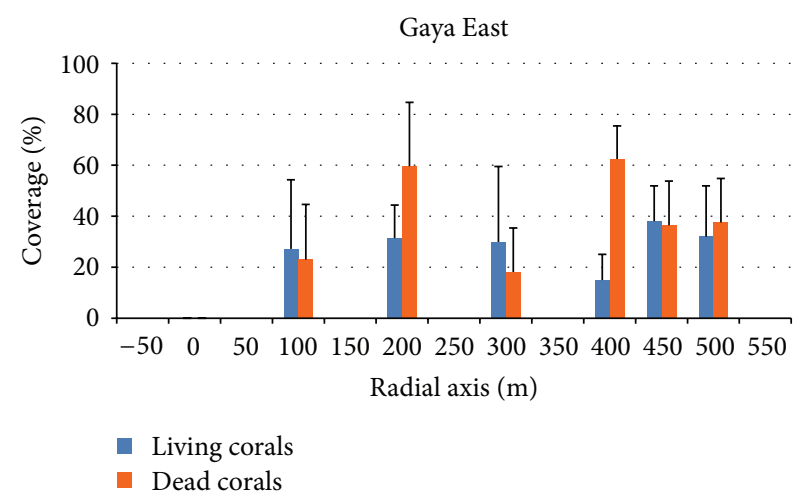

(b)

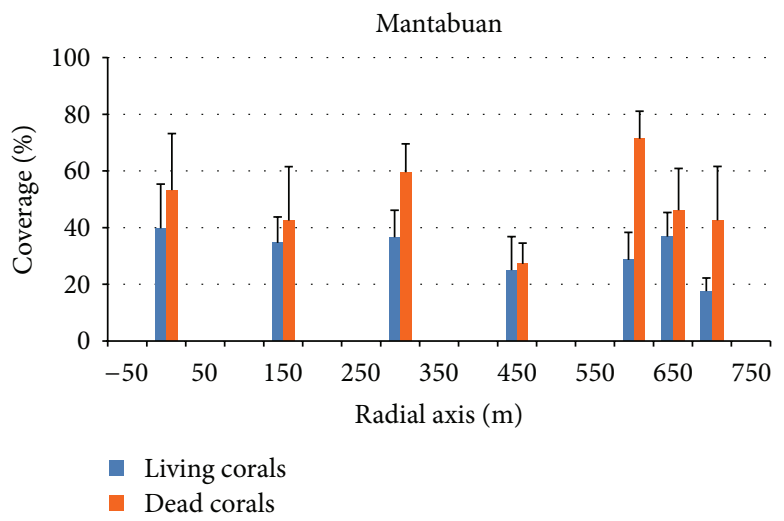

(c)

FIGURE 8: Mean percentage (and SD) of coverage of living and dead corals at each station. In Gaya West (a) and Gaya East (b) sites, the two last stations on the right are located on the outer slope. In Mantabuan (c), the three last stations on the right are located on the outer slope.

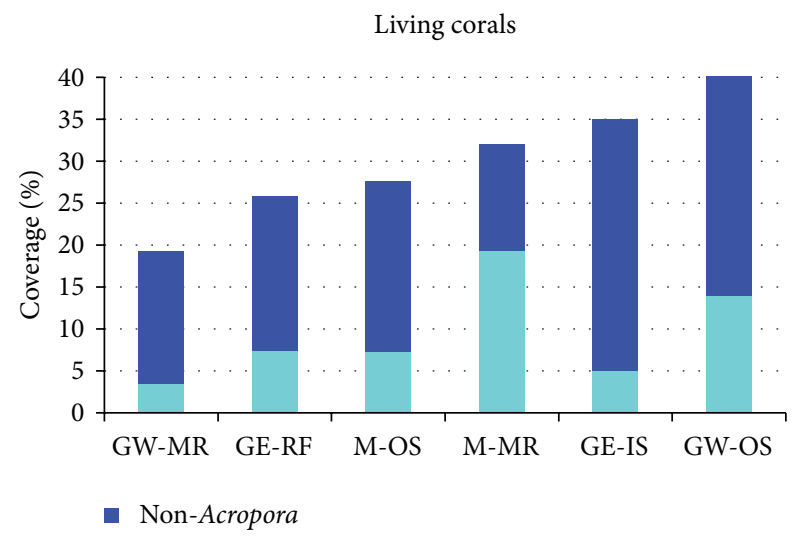

FIGURE 9: Increasing mean percentage of coverage of living corals, with Acropora and non-Acropora, in lagoons (MR: mesh reef and RF: reef flat) and slopes (IS: inner slope and OS: outer slope). Sites: GW: Gaya West, GE: Gaya East, and M: Mantabuan.

while they form a reef flat in Gaya East (Table 2). In Gaya West and Mantabuan lagoons, LITs were placed on the upper parts of the mesh reef rims, which is why the bioconstructed mean coverage reaches almost $80 \%$ (Table 4 ). Although other LITs were placed randomly on the outer slopes and on the fringing
TABLE 3: Percentage of coverage of primary producers (macroalgae and filamentous algae). Mean (SD).

\begin{tabular}{lc}
\hline Sites & Primary producers \\
\hline Gaya West-mesh reef & $3.1(4.5)$ \\
Gaya West-outer slope & $0.0(0.0)$ \\
Gaya East-reef flat & $8.1(23.6)$ \\
Gaya East-inner slope & $2.7(8.5)$ \\
Mantabuan-mesh reef & $4.0(7.5)$ \\
Mantabuan-outer slope & $2.7(5.4)$ \\
\hline
\end{tabular}

reef of Gaya East (reef flat and inner slope), the percentage of coverage of "bioconstructed" substrates is exceptionally high, generally around $70 \%$.

3.3. Vitality of Corals. The living coral coverage is approximately $\leq 50 \%$ of the bioconstructed substrates on the three sites. Considering the different subsites (Table 4), the vitality of corals is the highest in the Gaya West outer slope and the Gaya East inner slope (resp., almost 60 and 50\% of living corals within the bioconstructed substrates).

When all the different stations are taken into consideration (Figure 8), it appears that dead corals dominate over living corals in almost all the stations, except on the outer 
TABle 4: Percentage of coverage of living and dead corals on the different geomorphological zones and vitality (relative percentage of living corals/totality of bioconstructed substrates). Mean (SD).

\begin{tabular}{|c|c|c|c|c|}
\hline Site-subzone & Living corals & Dead corals & Bioconstructed substrates & Vitality (\%) \\
\hline Gaya West-mesh reef & $19.6(14.2)$ & $60.5(21.2)$ & $80.0(22.2)$ & 24.5 \\
\hline Gaya West-outer slope & $44.8(19.9)$ & $30.3(11.3)$ & $75.1(26.0)$ & 59.7 \\
\hline Gaya East-reef flat ${ }^{*}$ & $25.9(7.5)$ & $40.8(23.5)$ & $66.7(35.6)$ & 38.8 \\
\hline Gaya East-inner slope & $35.0(4.3)$ & $37.0(0.7)$ & $72.0(19.7)$ & 48.6 \\
\hline Mantabuan-mesh reef & $34.0(6.4)$ & $45.6(14.2)$ & $79.6(21.4)$ & 42.7 \\
\hline Mantabuan-outer slope & $27.7(9.7)$ & $53.4(15.7)$ & $81.1(21.2)$ & 34.1 \\
\hline
\end{tabular}

${ }^{*}$ Except LIT GE1 totally sandy. Vitality = Living corals/Dead corals $* 100$.

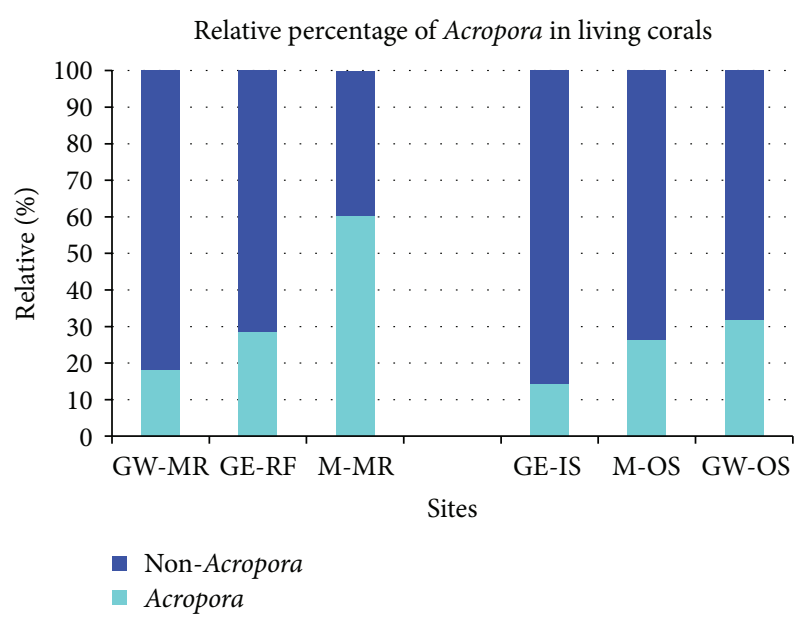

FIGURE 10: Increasing mean relative percentage of coverage of living Acropora: left, in lagoons (MR: mesh reef and RF: reef flat) and right: on slopes (IS: inner slope and OS: outer slope). GW: Gaya West, GE: Gaya East, and M: Mantabuan.

TABLE 5: Percentage of coverage of corals affected by hypersedimentation in the different geomorphological zones. Mean (SD).

\begin{tabular}{lc}
\hline Site-subzone & Corals affected by hypersedimentation \\
\hline Gaya West-mesh reef & $4.5(3.4)$ \\
Gaya West-outer slope & $2.0(3.6)$ \\
Gaya East-reef flat* & $13.2(17.9)$ \\
Gaya East-inner slope & $7.4(8.8)$ \\
Mantabuan-mesh reef & $0.5(1.4)$ \\
Mantabuan-outer slope & $4.3(8.2)$ \\
\hline
\end{tabular}

* Except LIT GE1 without corals.

slope of Gaya West and on one station of the Gaya East-reef flat. The stations located on Gaya West-mesh reef have the lower vitality.

\subsection{Living Corals}

3.4.1. Acropora versus Other Corals. As shown in Figure 9, the living coral coverage is maximal on the outer slope of Gaya West and on the inner slope of Gaya East. It is minimal on Gaya West-mesh reef whereas LITs have been spread only on the upper part of coral rims.

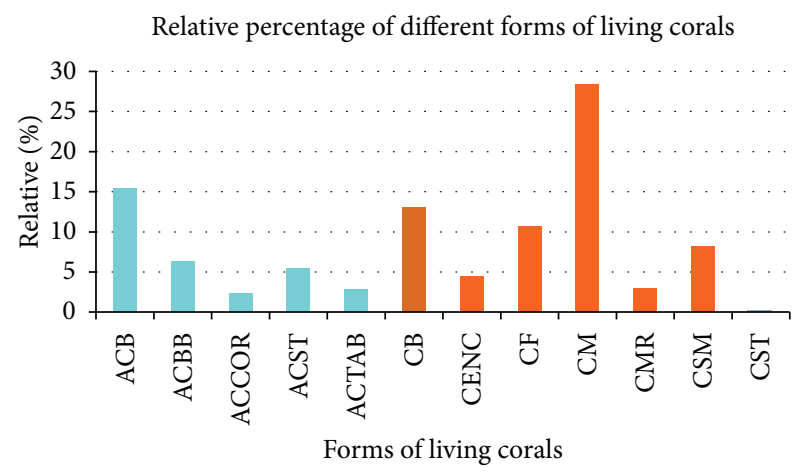

FIGURE 11: Living corals, all sites together. Relative percentage of the different coral forms occurring on the three sites. ACB: branching Acropora; ACBB: bottlebrush Acrop.; ACCOR: corymbose Acrop.; ACST: stout Acrop.; ACTAB: tabular Acrop.; CB: branching nonAcrop.; CENC: encrusting corals; $\mathrm{CF}$ : foliaceous corals; CM: massive corals; CMR: mushroom corals; CSM: submassive non-Acrop.; CST: stout non-Acrop.

Acropora colonies constitute 19 and $14 \%$ of the total coverage in Mantabuan-mesh reef and Gaya West-outer slope, that is, $60 \%$ and $30 \%$, respectively, of the relative coverage of living corals (Figure 10). In the other sites, Acropora coverage is always lower than $30 \%$ of the living corals and even lower than $20 \%$ on Gaya West-mesh reef.

3.4.2. Living Corals: The Different Forms. Considering all the stations together (Figure 11), the dominant living coral forms are (1) the massive corals (-CM-, notably here massive Porites and Faviidae), (2) the branching Acropora -ACB-, (3) the branching non-Acropora (-CB-, represented here by branching Porites, Pocillopora, Stylophora, Seriatopora, etc.), and (4) the foliaceous corals -CF-, such as Montipora of florida, Pavona cf cactus.

Considering now each subsite (Figure 12), it appears that the highest diversity in coral forms is reached in the Gaya West-outer slope where the living coral coverage is the highest: massive and foliaceous corals dominate, along with branching Acropora.

The diversity of forms is also high in the Mantabuanmesh reef (with a dominance of branching Acropora) and in the Gaya East-reef flat where large monospecific stands of Montipora cf florida, branching Acropora sp. or Pavona cf 


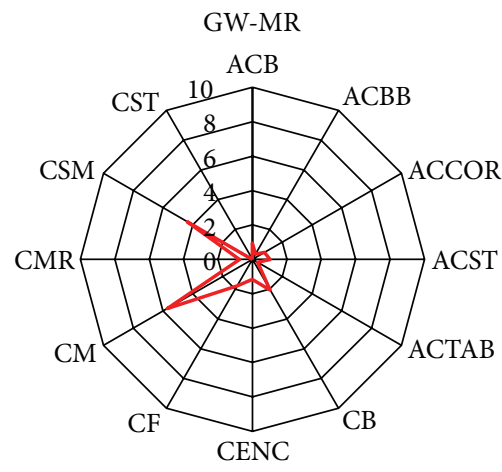

(a)

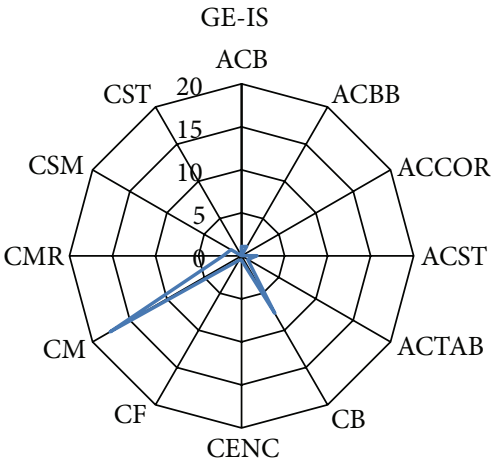

(d)

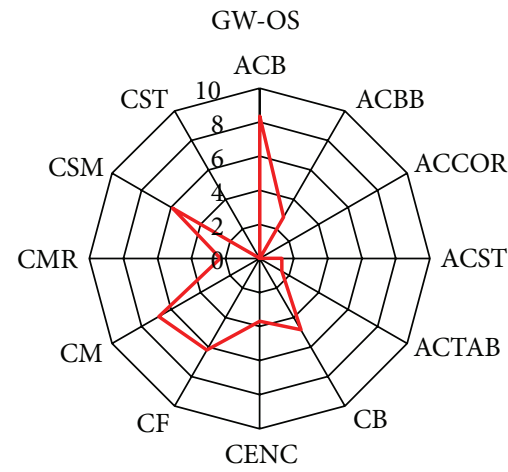

(b)

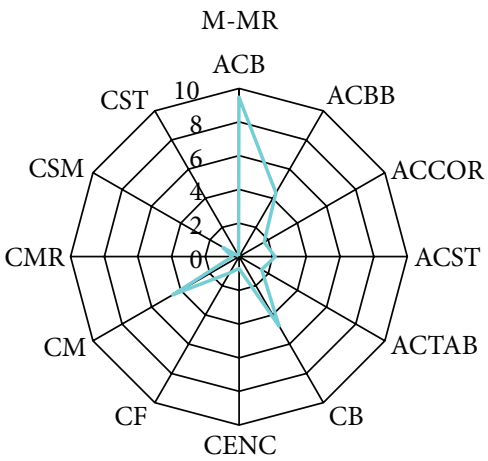

(e)

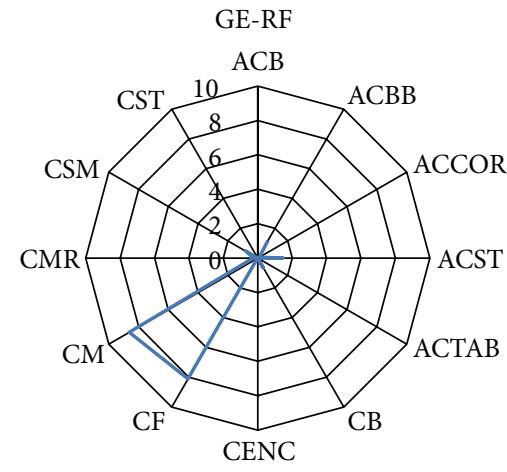

(c)

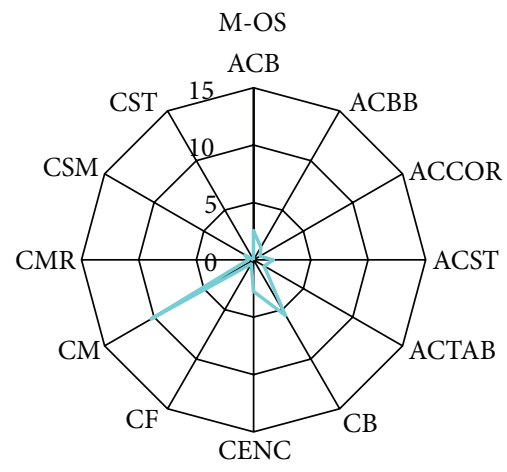

(f)

FIGURE 12: Percentage of coverage of different forms of living corals on each site (GW: Gaya West; GE: Gaya East; M: Mantabuan; MR: mesh reef; RF: reef flat; OS: outer slope; IS: inner slope). ACB: branching Acropora; ACBB: bottlebrush Acrop.; ACCOR: corymbose Acrop.; ACST: stout Acrop.; ACTAB: tabular Acrop.; CB: branching non-Acrop.; CENC: encrusting non-Acrop.; CF: foliaceous corals; CM: massive corals; CMR: mushroom corals; CSM: submassive corals; CST: stout non-Acrop.

TABLE 6: Number of individuals per $10 \mathrm{~m}^{2}$ in the different subsites. Mean (SD).

\begin{tabular}{lcccccc}
\hline Site-subzone. $N$ ind. $/ 10 \mathrm{~m}^{2}$ & Echinids & Asterids & Holothurids & Crinoids & Tridacna & Nudibranchs \\
\hline Gaya West-mesh reef & $10.0(21.7)$ & $0.6(0.9)$ & $0.2(0.5)$ & $0.2(0.5)$ & $0.1(0.2)$ & $0.5(0.3)$ \\
Gaya West-outer slope & $0.4(0.6)$ & $1.4(0.3)$ & $0.6(0.8)$ & $0.4(0.6)$ & $0.2(0.3)$ & $1.4(0.3)$ \\
Gaya East-reef flat ${ }^{*}$ & $15.4(13.9)$ & $0.4(0.3)$ & $0.2(0.3)$ & $0.4(0.8)$ & $2.0(1.0)$ & $0.1(0.1)$ \\
Gaya East-inner slope & $7.5(7.5)$ & $0.1(0.1)$ & $0.0(0.0)$ & $3.1(2.7)$ & $0.9(1.0)$ & $0.2(0.3)$ \\
Mantabuan-mesh reef & $4.2(3.5)$ & $0.7(0.7)$ & $0.0(0.0)$ & $7.4(13.7)$ & $1.1(1.3)$ & $0.0(0.0)$ \\
Mantabuan-outer slope & $3.8(0.5)$ & $0.7(0.0)$ & $0.5(0.1)$ & $10.5(4.5)$ & $0.7(0.8)$ & $0.1(0.1)$ \\
\hline
\end{tabular}

${ }^{*}$ Except LIT GE1 exclusively sandy.

TABLE 7: Estimation of the number of individuals per $100 \mathrm{~m}^{2}$ in the different subsites, using abundance index. Mean (SD).

\begin{tabular}{lccc}
\hline Site-subzone. $N$ ind. $/ 100 \mathrm{~m}^{2}$ & Stegastes & Parrotfish & Other fish \\
\hline Gaya West-mesh reef & $71.1(84.5)$ & $6.0(7.0)$ & $17.1(22.3)$ \\
Gaya West-outer slope & $34.5(29.7)$ & $34.5(29.7)$ & $110.3(151.7)$ \\
Gaya East-reef flat* & $233.8(18.8)$ & $4.1(6.4)$ & $5.6(5.3)$ \\
Gaya East-inner slope & $233.8(23.0)$ & $8.3(7.4)$ & $136.5(114.6)$ \\
Mantabuan-mesh reef & $185.1(72.4)$ & $48.0(94.9)$ & $26.1(27.2)$ \\
Mantabuan-outer slope & $34.5(29.7)$ & $152.8(137.5)$ & $>250(0.0)$ \\
\hline
\end{tabular}

${ }^{*}$ Except LIT GE1 exclusively sandy. 


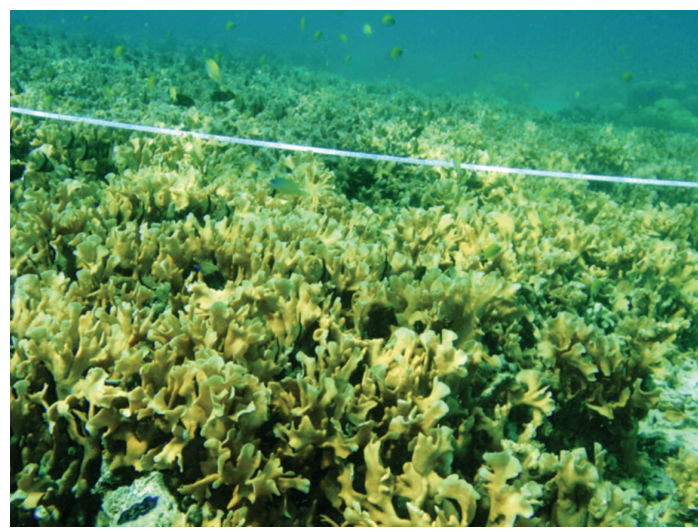

FIgURE 13: Gaya East-reef flat: large monospecific stand of Pavona.

cactus, occur (Figure 13). These stands alternate with patches rich in massive corals, made of large Porites cf lobata and numerous Faviidae (Favia, Favites, Goniastrea, etc.).

The last three subsites, Gaya West-mesh reef, Gaya Eastinner slope, and Mantabuan-outer slope, show a low diversity in coral forms and are dominated by massive corals.

\subsection{Principal Component Analysis on Benthos Data (PCA).} PCA on data shows that axes 1 and 2 explain $48.1 \%$ of the variance. Factor 1 (PC1) accounting for $27.7 \%$ of the variance is largely determined by the opposition between the occurrence of a high coverage of living corals, mostly foliaceous and branching Acropora in stations GE2, GE4, and GE6, against the occurrence of juvenile living corals settled on bare substratums (thus a facies of recovery) in M1 and M5 (Figure 14(a)). The coral communities on Gaya East-fringing reef are then more ancient than in Mantabuan.

Factor 2 (F2) accounting for $20.4 \%$ of the variance depends mainly on the opposition between a high coverage of foliaceous corals (GE2) and a high coverage of massive corals in GE6 and GE7.

Factor 3 (13.9\% of var.) opposes young branching Acropora settled on dead substratums in M1 and young submassive corals settled on dead substratums on GW1 and GW7 (Figure 14(b)), both facies of recovery.

3.6. Corals Affected by Hypersedimentation. Corals affected by hypersedimentation do not represent a high percentage of coverage (Table 5). The higher percentage is observed on the fringing reef of Gaya East, reef flat and inner slope.

3.7. Echinoderms, Tridacna, and Nudibranchs. Echinids (or sea urchins), mostly Diadema, are numerous on Gaya Eastreef flat (more than 1.5 individual per $\mathrm{m}^{2}$ ) and on Gaya West-mesh reef ( 1 individual per $\mathrm{m}^{2}$ ) (Table 6 ). They are surprisingly not abundant on Mantabuan-mesh reef $(0.4$ individual per $\mathrm{m}^{2}$ ).

Asterids (or sea stars) and holothurids (or sea cucumbers) are scarce and are the most abundant on Gaya West-outer slope (0.1 individual per $\mathrm{m}^{2}$ resp.).
Crinoids are the most abundant on Mantabuan-mesh reef and -outer slope: 0.7 and 1.0 individual per $\mathrm{m}^{2}$, respectively.

Tridacna are abundant on the reef flat of Gaya East $(0.2$ individual per $\mathrm{m}^{2}$ ), on Mantabuan-mesh reef, and on Gaya East-inner slope ( 0.1 individual per $\mathrm{m}^{2}$ ).

The gastropods nudibranchs are abundant in Gaya Westouter slope and -mesh reef $\left(0.1\right.$ and 0.05 individual per $\mathrm{m}^{2}$, resp.).

Considering the sedentary fauna on the whole (Figure 15), it appears that the two subsites of Gaya East and the subsite of Gaya West-mesh reef are dominated by sea urchins, while Mantabuan (mesh reef and outer slope) is much more dominated by crinoids. The subsite Gaya West-outer slope is the only one where the six groups of fauna are slightly dominated by starfish and nudibranchs.

3.8. Fish. The damselfish Stegastes is particularly abundant on Gaya East-reef flat and -inner slope, while parrotfish are the most abundant in Mantabuan-outer slope and more moderately abundant on the mesh reef (Table 7). The other fish are very abundant ( $>250$ ind. per $\mathrm{m}^{2}$ ) on the Mantabuanouter slope.

Regarding the total fish community (Figure 16), it appears that the Mantabuan-outer slope and the Gaya East-inner slope encompass numerous fishes, but the Gaya East fish community is dominated by Stegastes while the Mantabuan fish community is much more diversified and includes numerous parrotfish.

\section{Discussion}

4.1. Primary Producers. The fast growth and turnover rates of fleshy algae highlight their value as early warning indicators of reef degradation. Except in some places on the reef flat of Gaya East and the upper parts of strips of Gaya West, primary producers are scarce. Thus, not a single sign of eutrophication has been recorded, and algae cannot be considered as a potential danger to living corals in the studied areas. Nevertheless, further investigations during the hot and very wet season are needed to better understand the role of the primary producers on these reefs.

4.2. Coral Vitality. In the studied stations, the bioconstructed coverage (living and dead corals) is exceptionally high (67$81 \%$ of mean coverage). However, the coral vitality varies. It reaches $60 \%$ on the Gaya West-outer slope ("fair" condition), $49 \%$ on the Gaya East-inner slope, $43 \%$ on the Mantabuanmesh reef, and $24 \%$ on the Gaya West-mesh reef ("poor" condition).

On the Gaya West-mesh reef, LITs have been spread only on bioconstructed substrates. Nevertheless, the bioconstructed coverage is relatively low because large basins of sand and rubble occur on the upper parts of the coral rims.

Reticulated reefs display very different facies and vitality levels in Gaya and Mantabuan: in the Gaya West lagoon, coral rims (4-7 m high, 4-5 m wide) occur in a very turbid environment and have a vitality of $24 \%$. In the Mantabuan lagoon, corals are organized in smaller rims $(4 \mathrm{~m}$ high, $3 \mathrm{~m}$ 


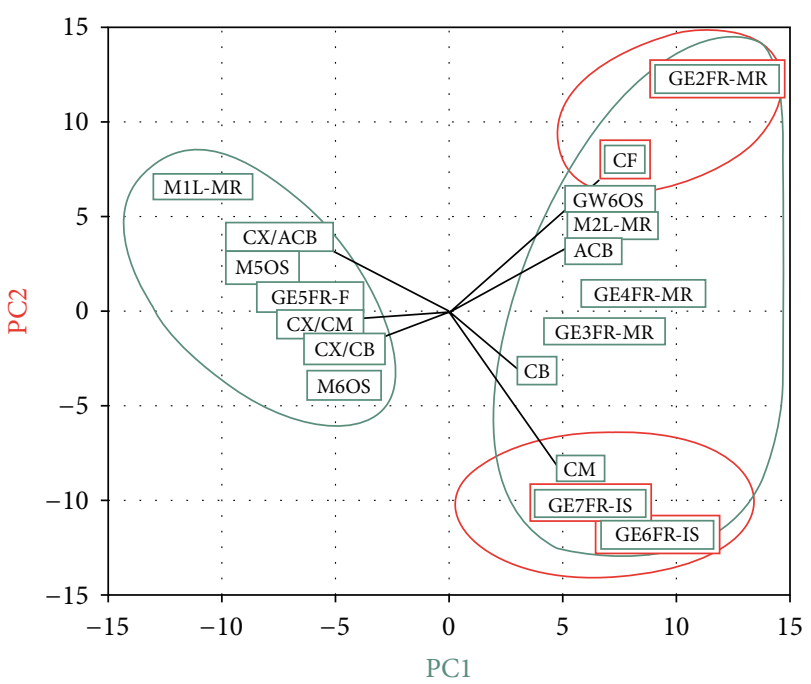

(a)

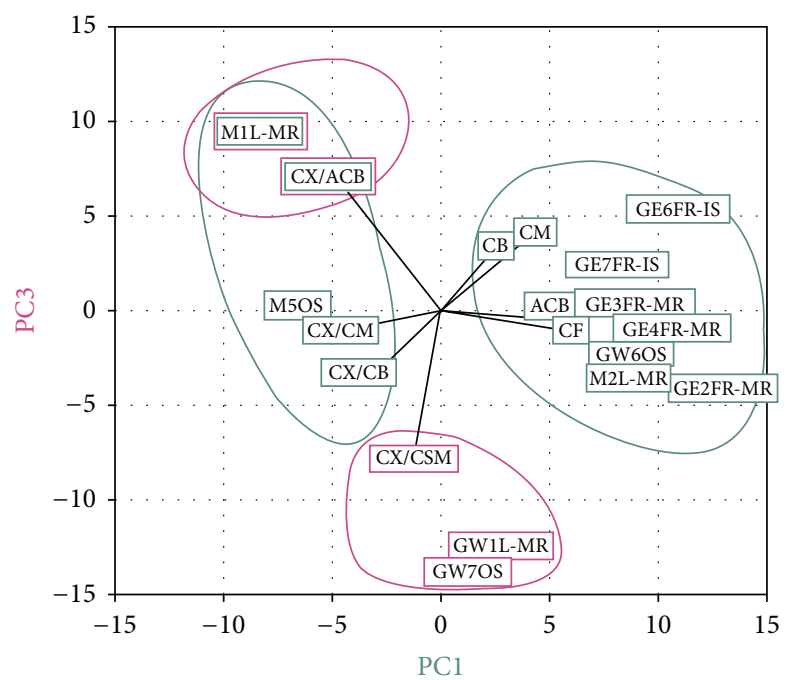

(b)

FIGURE 14: PCA on all data (GW: Gaya West; GE: Gaya East; M: Mantabuan; MR: mesh reef; RF: reef flat; OS: outer slope; IS: inner slope). ACB: branching Acropora; ACBB: bottlebrush Acrop.; ACCOR: corymbose Acrop.; ACST: stout Acrop.; ACTAB: tabular Acrop.; CB: branching non-Acrop.; CENC: encrusting non-Acrop.; CF: foliaceous corals; CM: massive corals; CMR: mushroom corals; CSM: submassive corals; CST: stout branching non-Acrop; CX/ACB: branching Acrop. sur dead substrate, CX/ACBB: etc.

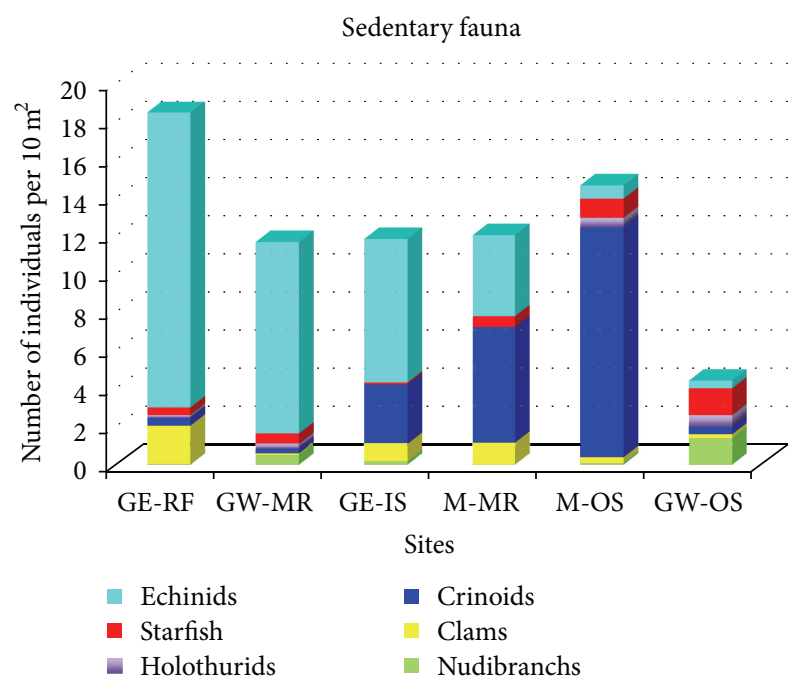

FIGURE 15: Mean of number (nb) of individuals of sedentary fauna recorded on each site. Continuum from dominance of sea-urchins on the left to dominance of crinoids on the right (GW: Gaya West; GE: Gaya East; M: Mantabuan; MR: mesh reef; RF: reef flat; OS: outer slope; IS: inner slope).

wide) and occur in clear water; the vitality is $43 \%$, and Acropora forms $60 \%$ of the living corals. According to Edinger and Risk [29], the occurrence of abundant Acropora is linked to good health, as Acropora is an r-strategist and a very sensitive form of coral. Generally, the Acropora-dominated reefs harbor a high diversity of associated fish [30].

On the Gaya East-fringing reef (reef flat and inner slope), we observed the highest percentage of corals affected by hypersedimentation. It is likely that the funnel shape of the
Fish

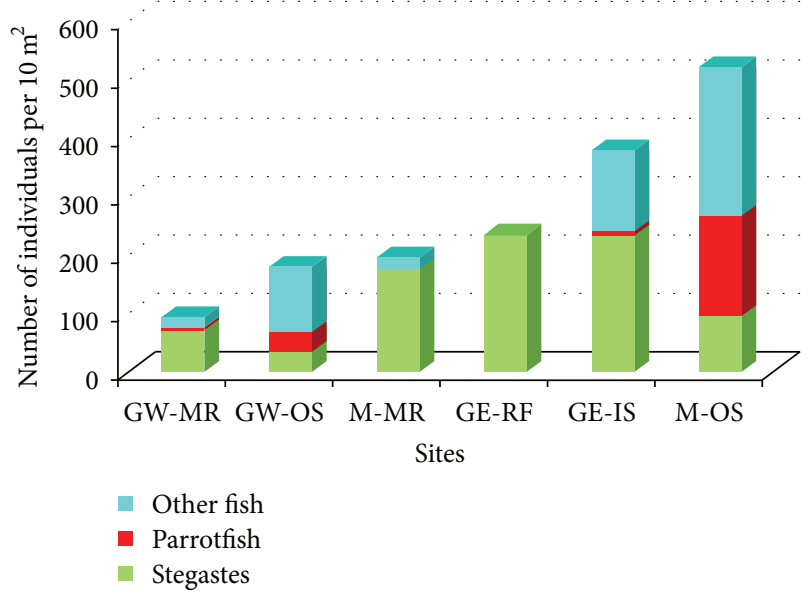

FIGURE 16: Mean of increasing abundance of fish (GW: Gaya West; GE: Gaya East; M: Mantabuan; MR: mesh reef; RF: reef flat; OS: outer slope; IS: inner slope).

fringing reef and the strong current occurring between the two islands are at the origin of this increased sedimentation. On the reef flat, the station GE2 (Gaya East-reef flat) is highly characterized by foliaceous corals (such as Pavona cf cactus and Montipora cfflorida) that develop in monospecific stands (circa $10 \mathrm{~m}$ wide). On the other hand, the Gaya East-inner slope is highly characterized by massive corals. Gaya East (reef flat and inner slope) is also characterized by a high density of Stegastes damselfish (more than 200 per $100 \mathrm{~m}^{2}$ ). This is an indication of coral degradation. 
In Peninsular Malaysia, one of the major reasons for the "poor" to "fair" conditions of hard corals may be due to increases in sedimentation [31]. Along the west coast of Peninsular Malaysia, heavy sedimentation has caused serious siltation problems in some river mouths and harbors [32]. Millions of tons of sediment are transported annually by major rivers of the east coast of Sumatra and the west coast of Peninsular Malaysia to the coastal waters of the Malacca Straits [33]. In many localities, these huge amounts of sediment have changed the physical, chemical, and biological environment of the coral reefs. Therefore, coral vitality is very low in the area [34].

In our study, coral communities display a different state of evolution: corals in the lagoon of the Mantabuan-mesh reef are in state of recovery while on the Gaya East-reef flat they have reached a mature status. Thus, large bleaching/mortality events may have affected some reefs of the Tun Sakaran Marine Park such as the Mantabuan ones.

4.3. Sea Urchins. Sea urchins, such as Diadema, are highly represented on the Gaya East-reef flat and the Gaya Westmesh reef. On the Gaya West-mesh reef, macroalgae such as Caulerpa spp. occur within corals; on Gaya East, large Ochrophytes occur as metric sporadic stands. These primary producers can attract Diadema, a big consumer of seaweed.

On the Mantabuan-mesh reef, the sea urchins are scarce. As the corals are at the stage of recovery, the sea urchin populations may have been affected by the same mortality as the corals. This would explain the low density of sea urchins on this reef. Nevertheless, the primary producers remain very scarce in this area; thus, they may be controlled by herbivorous organisms. Additional investigations are needed on sea urchin and fish herbivory to better understand the functioning of this beautiful area.

4.4. Fishes. The fish community is thriving on the Mantabuan-outer slope where a myriad of fish exist around corals. In the three lagoons, but also on the Gaya East-inner slope, the Stegastes damselfish dominates. On Mantabuan, parrotfish are particularly abundant on the outer slope. They are also present into the lagoon around the mesh reef.

4.5. Coral Degradation. Concerning the low vitality observed in the Gaya West-mesh reef, Bell and Galzin [24], studying reticulated reefs (Mataiva atoll, Tuamotu Archipelago, and French Polynesia), explained that several "lagoon basins" somewhat closed by the coral rims were entirely or partially dead (the cause of mortality was uncertain). Perhaps this "closing" process of the mesh reefs explains the coral degradation into the lagoons (i.e., Mataiva or Gaya bank).

Bodgaya is an inhabited island with a significant fishing pressure inside the lagoon (particularly on Gaya West). This pressure might explain the scarcity of fish. Thus, an overfishing might speed up a disequilibrium in the ecosystem via (1) the reduction of fish (and perhaps sea urchin) herbivory and/or (2) the demise of key species. Further studies are needed (1) to estimate the impact of fishing and harvesting by the local population, (2) to identify the target species, and
(3) to research potential new species that could bring food or money to the locals. If fishing by the local population impacts too much on the lagoon communities, a range of measures (such as aquaculture) have to be proposed to reduce fishing pressure and allow overexploited fish populations to recover and ensure the maintenance of healthy populations.

Experiments are also needed to estimate the real impact of local populations and tourism (mostly divers). For example, restoration via coral nubbins may be attempted on some degraded parts of the Gaya lagoon, which would be protected from human impact. Also, the Mantabuan lagoon may be an ideal control site for experimentation.

\section{Conclusion}

TSMP belongs to the Coral Triangle region. Known as the "Amazon of the Seas" and one of the world's most diverse and threatened marine ecosystems, the Coral Triangle encompasses ocean areas in six countries in Southeast Asia and the Pacific (Indonesia, Malaysia, Papua New Guinea, Philippines, Solomon Islands, and Timor-Leste). This region is recognized as the global centre of marine biodiversity [35] and a global priority for conservation [36]. Covering 5.7 million square kilometers of ocean waters, it contains at least 500 species of reef-building corals in each ecoregion [37]. More than 2,200 species of fish (including the largest fish species, the whale shark, and the coelacanth) live there. It also provides a habitat to six out of the world's seven marine turtle species.

The coral fauna of the TSMP shows a clear affinity with that found on Indonesian reefs, and several species (including some rare species of Acropora and the uncommon caryophylliid Nemenzophyllia turbida [2]) are new to Malaysia. A number of the sponges and soft corals found in the Gaya lagoon are new undescribed species. One sponge is reported to be very unusual and possibly endemic to the Semporna reefs [9]. Also, Allen [1] found two new species of damselfish there.

Tun Sakaran Marine Park provides as much as 21 prestigious scuba diving sites, for example, Tabah Siramba (Church Reef), Kapikan Reef, Ribbon Reef, Mantabuan, and Sibuan Reef. Divers and snorkelers enjoy various attractive marine lives such as turtles, eagle rays, barracudas, bumphead parrotfish, nudibranchs, and recently discovered sponges. It is difficult to describe the thrills that divers experience when they encounter marine macrolife in the Bodgaya lagoon. It is therefore important that something be done to prevent further degradation of this natural wonderland.

\section{Acknowledgments}

This research project, carried out at the South-East Asia Carbonate Research Laboratory (SEACARL), is financed by a Shell grant to Universiti Teknologi Petronas (Malaysia), French Embassy (Malaysia), University of South-Brittany (France), the Bretagne Region (CARBASIA project), and the Conseil Général du Morbihan. The authors wish to thank Sabah Parks for granting them a research permit to work 
in Tun Sakaran Marine Park. They wish to express their gratitude to the staff of Sabah Parks Kota Kinabalu, Semporna, and Boheydulang station for their invaluable help and support during the field visits to Tun Sakaran Marine Park. The authors also wish to thank the staff of the Oceanography Institute of Universiti Malaysia Terengganu for their help with the acquisition of the bathymetry data. Thanks are also due to Lawrence Schwarz for improving the English language of the paper.

\section{References}

[1] G. R. Allen, "Marine fishes of Sabah, Northern Borneo," in Proposed Semporna Marine Park: Environmental Evaluation for Expanded Tourism Development, T. D. Meagher, Ed., pp. 53-70, 1992.

[2] E. M. Wood, Management Plan for the Semporna Islands Park, Proposed Through the Semporna Islands Project (SIP), Sabah Parks, Marine Conservation Society (MCS), WWF Malaysia, Nature Link, 2001, http://www.sempornaislandspro ject.com/pages/publications.htm.

[3] A. Harborne, D. Fenner, A. Barnes, M. Beger, S. Harding, and T. Roxburgh, Status Report on the Coral Reef of the East Coast of Peninsular Malaysia, Coral Cay Conservation, London, UK, 2000.

[4] T. D. Meagher, Ed., Proposed Semporna Marine Park: Environmental Evaluation for Expanded Tourism Development, Conbata Pty, Perth, Australia, 1992.

[5] J. D. George and J. George, "The coral reefs of the Bodgaya Islands (Sabah: Malaysia) and Pulau Sipadan. 4. Macroinvertebrates," Malayan Nature Journal, vol. 40, no. 3-4, pp. 225-260, 1987.

[6] F. A. Dipper, Notes on Sponges from the Proposed Semporna Islands Park. A Report for the Semporna Islands Project, Marine Conservation Society, 2001.

[7] L. M. Marsh, "Echinoderms of the Tunku Abdul Rahman Park, reefs off Semporna and Pulau Sipadan," in Proposed Semporna Marine Park: Environmental Evaluation for Expanded Tourism Development, T. D. Meagher, Ed., pp. 55-59, Conbata Pty, Perth, Australia, 1992.

[8] D. J. W. Lane, "Macroinvertebrates 2," in Pulau Sipadan: Reef Life and Ecology, WWF Project No. MYS 233/92, pp. 71-80, 1994.

[9] M. Kelly, "Notes on sponge species identifications. A report for the Semporna Islands Project," 1999.

[10] Semporna Marine Ecological Expedition, December 2010, http://awsassets.panda.org/downloads/smee_factsheet_dec_ 2010.pdf.

[11] R. F. Baptist, D. Lojiwin, and D. Kubud, Report on Human Settlements in Semporna Islands Proposed Park, Sabah Museum, 1998.

[12] B. J. Pierson, D. Menier, A. Chalabi, and T. King King, "Morphological indicators of growth stages in carbonates platform evolution: comparison between present-day and Miocene platforms of Northern Borneo, Malaysia," in Proceedings of the EGU General Assembly, vol. 14 of Geophysical Research Abstracts. EGU2012-12815-2, Vienna, Austria, April 2012.

[13] D. Menier, B. J. Pierson, A. Chalabi, T. King King, and M. Pubellier, "Morphological indicators of structural control,relative sealevel fluctuations and platform drowning on present-day and miocene carbonate platforms," Marine and Petroleum Geology. In press.
[14] J. H. Schroeder and D. H. Nasr, "The fringing reefs of Port Sudan, Sudan. 1. Morphology, Sedimentology, Zonation," Essener Geographische Arbeiten, vol. 6, pp. 29-44, 1983.

[15] S. J. Purkis and B. Riegl, "Spatial and temporal dynamics of Arabian Gulf coral assemblages quantified from remote-sensing and in situ monitoring data," Marine Ecology Progress Series, vol. 287, pp. 99-113, 2005.

[16] A. Guilcher, "Coral reef geomorphology," Norois, vol. 142, no. 1, pp. 234-236, 1988.

[17] D. R. Stoddart, "Ecology and morphology of recent coral reefs," Biological Reviews, vol. 44, pp. 433-498, 1969.

[18] E. G. Purdy, "Reef configurations: cause and effect," in Reefs in Time and Space, L. F. Laporte, Ed., vol. 18 of Society of Economic Paleontologists and Mineralogists Special Publication, pp. 9-76, 1974.

[19] R. A. Slater and C. V. T. Phipps, "A preliminary report on the coral reefs of Lord Howe island and Elizabeth reef, Australia," in Proceedings of the 2nd International Coral Reef Symposium, vol. 2, pp. 313-318, Miami, Fla, USA, 1977.

[20] J. F. Marshall and P. J. Davies, "Internal structure and Holocene evolution of One Tree Reef, southern Great Barrier Reef," Coral Reefs, vol. 1, no. 1, pp. 21-28, 1982.

[21] D. Hopley, S. G. Smithers, and K. E. Parnell, The Geomorphology of the Great Barrier Reef: Development, Diversity, and Change, Cambridge University Press, Cambridge, UK, 2007.

[22] J. C. Kenyon, C. B. Wilkinson, and G. S. Aeby, "Community structure of hermatypic corals at maro reef in the northwestern Hawaiian islands: a unique open atoll," Atoll Research Bulletin, no. 558, 22 pages, 2008.

[23] L. F. Montaggioni, "History of Indo-Pacific coral reef systems since the last glaciation: development patterns and controlling factors," Earth-Science Reviews, vol. 71, no. 1-2, pp. 1-75, 2005.

[24] J. Bell and R. Galzin, "Influence of live coral cover on coral reef fish communities," Marine Ecology Progress Series, vol. 15, pp. 265-274, 1984.

[25] K. L. Barott, J. E. Caselle, E. A. Dinsdale et al., "The lagoon at Caroline/Millennium atoll, Republic of Kiribati: natural history of a nearly pristine ecosystem," PLOS ONE, vol. 5, no. 6, Article ID e10950, 2010.

[26] H. A. Lucas and G. A. F. Seber, "Estimating coverage and particle density using the line intercept method," Biometrika, vol. 64, no. 3, pp. 618-622, 1977.

[27] Y. Loya, "Plotless and transect methods," in Coral Research Methods, D. R. Stoddart and R. E. Johannes, Eds., pp. 197-217, UNESCO, Paris, France, 1978.

[28] K. R. Clarke and R. M. Warwick, Change in Marine Communities: An Approach to Statistical Analysis and Interpretation, PRIMER-E, Plymouth, UK, 2nd edition, 2001.

[29] E. N. Edinger and M. J. Risk, "Reef classification by coral morphology predicts coral reef conservation value," Biological Conservation, vol. 92, no. 1, pp. 1-13, 2000.

[30] P. Chabanet, H. Ralambondrainy, M. Amanieu, G. Faure, and R. Galzin, "Relationships between coral reef substrata and fish," Coral Reefs, vol. 16, no. 2, pp. 93-102, 1997.

[31] T. Toda, T. Okashita, T. Maekawa et al., "Community structures of coral reefs around peninsular Malaysia," Journal of Oceanography, vol. 63, no. 1, pp. 113-123, 2007.

[32] T. E. Chua and S. A. Ross, "Creating a shared vision for environmental management in the straits of Malacca," in Tropical Marine Environment: Charting Strategies for the Millennium, F. M. Yusoff, M. Shariff, H. M. Ibrahim, S. G. Tan, and S. Y. 
Tai, Eds., pp. 19-33, Malacca Straits Research and Development Center (MASDEC), Faculty of Science and Environmental Studies, Putra University, Selangor, Malaysia, 2002.

[33] A. Soegiarto, "Pollution management and mitigation in the Straits of Malacca: priorities, uncertainties and décision making," in Towards Sustainable Management of the Straits of Malacca, M. Shariff, F. M. Yusoff, N. Gopinath, H. M. Ibrahim, and R. A. N. Mustapha, Eds., pp. 503-518, Malacca Straits Research and Development Center (MASDEC), Faculty of Science and Environmental Studies, Universiti Putra Malaysia, Selangor, Malaysia, 2000.

[34] A. Soegiarto, "The status of marine and coastal pollution in Southeast Asia," in Coastal Area Management in Southeast Asia: Policies, Management, Strategies and Case Studies, T. E. Chua and D. Pauly, Eds., vol. 19, pp. 71-75, ICLARM, Manila, Philippines, 1989.

[35] G. R. Allen, "Conservation hotspots of biodiversity and endemism for Indo-Pacific coral reef fishes," Aquatic Conservation, vol. 18, no. 5, pp. 541-556, 2008.

[36] J. C. Briggs, "The marine East Indies: diversity and speciation," Journal of Biogeography, vol. 32, no. 9, pp. 1517-1522, 2005.

[37] J. E. N. Veron, Corals of the World, vol. 3, Australian Institute of Marine Science and CRR; Qld Pty, Townsville, Australia, 2000, Edited by: M. Stafford-Smith. 

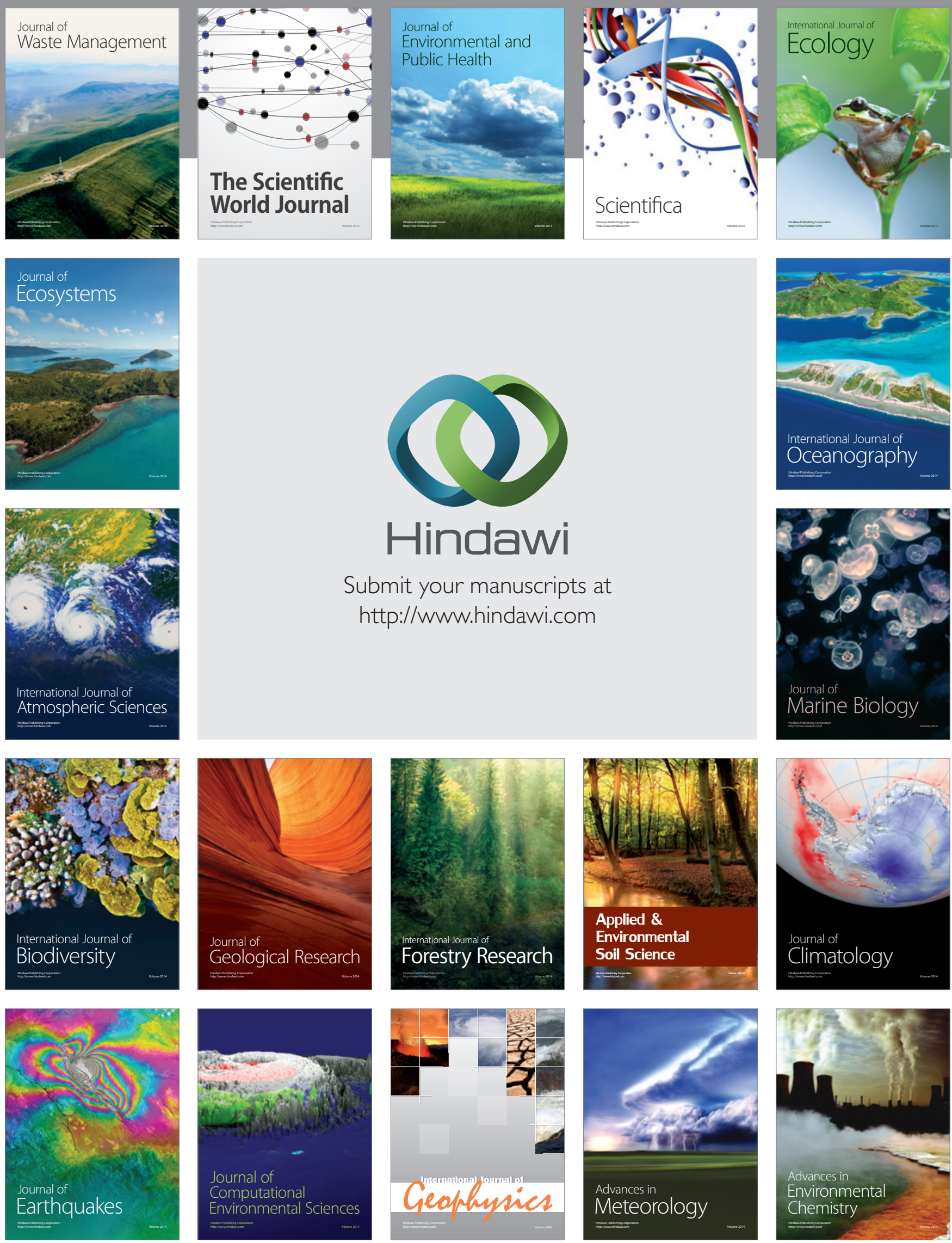